\title{
Effect of replacing the main reinforcement by steel fibers on flexural behavior of one-way concrete slabs
}

\author{
Muyasser Jomaa'h ${ }^{1, *}$, Ammar Khazaal ${ }^{1}$, and Sinan Ahmed ${ }^{1}$ \\ ${ }^{1}$ College of Engineering, Tikrit University, Tikrit, Iraq
}

\begin{abstract}
The main objective of the research is to study the preparation of one way slabs of ordinary concrete, and then to prepare concrete slabs by replacing the main reinforcing steel with two kinds of steel fibers (ordinary steel fibers and recycled steel fibers) by fraction volumes of $0.125,0.250$, and $0.375 \%$. Also, study the mechanical properties of the mixtures as a ompressive strength, indirect tensile strength, and flexural strength. Concrete slabs of these mixtures have been prepared with specific geometrical dimensions $700 * 300 * 70 \mathrm{~mm}$, exposed to line load, to study the bending moment and maximum failure load of these slabs. A concrete mixture was produced after proportionment based on the ACI and casting six cubes tested at the ages of 7 and 28 days where the strength requirements for design were achieved. The main mixtures of research were produced, three cubes for compressive strength testing, twenty one cylinders for indirect tensile strength testing, and twenty one prisms for modulus of rupture testing. Also sixteen concrete slabs were prepared, two of them were reference slabs without reinforcing steel, the other two with main reinforcing steel only, six of them replaced by the main reinforcing steel with ordinary steel fibers, and the last six replacing the main reinforcing steel with recycled steel fibers. The results showed that both the failure load and the resultant deflection in concrete slabs decreased by $(20.09 \%, 51.91 \%)$ for maximum load and by $(35.18 \%, 81.48 \%)$ compared to the reference slabs when replacing the main reinforcing steel with steel fiber, also by $(25.72 \%, 38.29 \%)$ to failure load and $(38.88 \%, 79.63 \%)$ for the deflection compared to the reference slabs when replacing the main reinforcing steel with recycled steel fibers. The best value for maximum load and deflection could be obtained from this study was at $0.125 \%$ replacement ratio of the main reinforcing steel with recycled steel fibers, the highest value of ductility was 3.77 at the replacement ratio of $0.250 \%$ of the main reinforcing steel with the ordinary steel fibers, also the highest hardness value was $11.67 \mathrm{kN} / \mathrm{mm}$ with the replacement ratio of $0.125 \%$ of the main reinforcing steel with recycled steel fibers and increased by $61.85 \%$ than the hardness of the reference slabs.
\end{abstract}

\section{Introduction}

Due to the increase in waste that adversely affects the environment, the researchers found many ways to get rid of these wastes and reduce their impact on the environment. It is known that reinforced concrete is used to build structures on a large scale all over the world. The reinforced concrete slabs are the main parts of these facilities. There are many analytical and experimental studies on reinforced concrete slabs. It has taken time and effort for many researchers and for many years. Concrete slabs are used as floors not only in industrial and residential buildings but also as floors in bridges. Portland cement concrete is also known as brittle when it is subjected to tensile stresses, unreinforced concrete cracks under these stresses. Since the middle of the 18th century steel reinforcement has been used to solve this problem. Using it in the concrete as a composite material, reinforcing steel supports all tensile stresses [1]. Concrete containing cement, water, fine and coarse aggregates, non-continuous fibers called as Fibrous Reinforced Concrete (FRC), has been widely used in the construction of roofs, paving, machinery foundations, and Seismic buildings [2]. Fibers are separate intermittent parts made of many materials such as steel, plastic, glass, and other natural materials of different shapes and sizes and the best numerical variable to define is the aspect ratio which is equal to the length of the fiber divided by the length of the equivalent diameter. The value of this ratio ranges (30-150) [3] Different labels for different types of fiber, as fiber can be divided into two groups according to the elasticity coefficient. The first fiber has a lower elasticity coefficient than the concrete elasticity coefficient, such as cellulose fibers, nylon and polypropylene fibers, and the second has a higher elasticity coefficient than the elasticity of concrete, such as asbestos fibers, fiberglass, iron fiber and carbon fiber [4]. It works to bridge cracks and increases the strength and durability of concrete. The effectiveness of this fiber depends on the pull-out resistance of the concrete mixture. When reinforced concrete is used in reinforced concrete beams then due to tensile strength the high tension of this type of concrete causes high tensile deformities in the longitudinal reinforcement bars. As a result, the reinforced concrete beams are acquired by the longitudinal reinforcing steel

* Corresponding author: muyasserjomaah@,tu.edu.iq 
and the steel fibers are highly ductile [5]. As for recycled steel fibers, they are a residue of vehicle tires or steel residues and their management remains a concern for those interested in the environment around the world. Therefore, researchers in Europe have sought to use tire waste as additives to concrete and to study their effect on concrete mixtures [6]. Materials are removed from damaged tires either mechanically or by burning. Mechanical methods produce rubber and steel. They start with the recycling of tire waste, turning tire residues into small pieces of rubber and then separating the raw rubber by freezing the parts to separate the tires. Rubber fracture which will be frosted and thus separating fiber after breaking rubber surrounded by and saved, and the method of burning produces steel including, coal, liquid and gases. It can be used as rubber and iron in concrete reinforcement as it works to increase the strength of concrete. Portability roads have hardness. It also can use the steel in it (with any type of steel fiber) as possible to reduce the amount of processed fiber used to increase construction speed, this can be used as waste tires to improve the energy and materials and reduce the buried material under the ground with the other uses, as the waste management FRAMEWORKS impact on the economy and national factors yield a practical example of this case. The frame of recycled recycling, where the demand is less than a new tire but it contributes to the reduction of prices depending on the level of use.

\section{Aim of study}

The purpose of this research is to study the structural and mechanical properties of reinforced concrete panels with steel fibers when used in wide beams (like one-way slab), and the possibility to take advantage of reinforcing fibers as a substitute for ordinary reinforcement, according to the study parameters and determinants process laboratory, and the possibility to take advantage of the fibers available or reuse of recycled steel fibers for concrete reinforcement with low cost, use of steel fibers from worn tire manufacturer as a substitute for fiber reinforced concrete as an alternative of synthetic steel fibers, it has proposed structural units with high strength and low cost used as concrete roofing.

\section{Experimental Program}

\subsection{Material preparation}

\subsubsection{Cement}

An ordinary Portland Cement Type I was used in all concrete mixtures. It conforms to the Iraqi Standard specification (IQS No.5 / 1984) [7]. Tables 1 and 2 show the chemical and physical properties of the cement used.

\subsubsection{Fine Aggregate}

The fine aggregate (sand) used was river sand from the short of river Dijla in Samarra area - Salah al-Din Governorate. It confirms to the Iraqi Standard
Specification/ zone III IQS NO.45 / 1984. Table 3 shows the grading of fine aggregate, and Table 4 shows the chemical and physical properties.

Table 1. Chemical properties of cement.

\begin{tabular}{|c|c|c|}
\hline $\begin{array}{c}\text { Oxides Composition } \\
{[8]}\end{array}$ & $\begin{array}{c}\text { Content } \\
\%\end{array}$ & $\begin{array}{c}\text { Limit of Iraqi } \\
\text { Specification No. } \\
5 / 1984[7]\end{array}$ \\
\hline $\mathrm{CaO}$ & 60.45 & - \\
\hline $\mathrm{Al}_{2} \mathrm{O}_{3}$ & 4.65 & $8 \% \mathrm{Max}$ \\
\hline $\mathrm{SiO}_{2}$ & 20.11 & $21 \% \mathrm{Max}$ \\
\hline $\mathrm{Fe}_{2} \mathrm{O}_{3}$ & 3.62 & $5 \% \mathrm{Max}$ \\
\hline $\mathrm{MgO}$ & 4.1 & $5 \% \mathrm{Max}$ \\
\hline $\mathrm{SO} 3$ & 2.33 & $2.5 \% \mathrm{Max}$ \\
\hline $\begin{array}{c}\text { Loss on Ignition, } \\
\text { (L.O.I) }\end{array}$ & 2.72 & $4 \% \mathrm{Max}$ \\
\hline Insoluble material & 1.33 & $1.5 \% \mathrm{Max}$ \\
\hline $\begin{array}{c}\text { Lime Saturation } \\
\text { Factor (L.S.F) }\end{array}$ & 0.89 & $(0.66-1.02)$ \\
\hline \multicolumn{2}{|c|}{} \\
\hline
\end{tabular}

Table 2. Physical properties of cement.

\begin{tabular}{|c|c|c|}
\hline Physical properties & $\begin{array}{c}\text { Test } \\
\text { Results }\end{array}$ & $\begin{array}{c}\text { Limit of Iraqi } \\
\text { Specification } \\
\text { No. } 5 / 1984\end{array}$ \\
\hline $\begin{array}{c}\text { Specific surface area } \\
\text { (Blaine method), } \\
\left(\mathrm{m}^{2} / \mathrm{kg}\right)[9]\end{array}$ & 308 & $\begin{array}{l}\left(230 \mathrm{~m}^{2} / \mathrm{kg}\right) \\
\text { lower limit }\end{array}$ \\
\hline $\begin{array}{l}\text { Setting time (Vacate } \\
\text { Apparatus) [10] } \\
\text { Initial setting, } \\
\text { (hrs : min) } \\
\text { Final setting, } \\
\text { (hrs : min) }\end{array}$ & $\begin{array}{l}\text { 2hrs: } 15 \mathrm{~min} \\
4 \mathrm{hrs}: 10 \mathrm{mn}\end{array}$ & $\begin{array}{l}\text { Not less than } \\
45 \mathrm{~min} \\
\text { Not more than } \\
10 \mathrm{hrs}\end{array}$ \\
\hline $\begin{array}{c}\text { Compressive strength } \\
\text { (MPa) [11] } \\
\text { For 3-day }\end{array}$ & 28.7 & $\begin{array}{c}\text { Not less than } \\
15 \mathrm{MPa}\end{array}$ \\
\hline
\end{tabular}

Table 3. Grading of fine aggregate.

\begin{tabular}{|c|c|c|c|}
\hline Sieve Size & $\begin{array}{c}\text { Cumulative } \\
\text { Retained \% }\end{array}$ & $\begin{array}{c}\text { Cumulative } \\
\text { Passing \% }\end{array}$ & $\begin{array}{c}\text { Limit of IQS } \\
\text { No. 45/1984 } \\
\text { for Zone No. } \\
(3)[12]\end{array}$ \\
\hline $\begin{array}{c}4.75-\mathrm{mm} \\
(\text { No.4) }\end{array}$ & 5.61 & 94.40 & $90-100$ \\
\hline $\begin{array}{c}2.36-\mathrm{mm} \\
(\text { No.8) }\end{array}$ & 8.62 & 91.35 & $85-100$ \\
\hline $\begin{array}{c}1.18-\mathrm{mm} \\
(\text { No.16) }\end{array}$ & 15.62 & 84.30 & $75-100$ \\
\hline $\begin{array}{c}600-\mu \mathrm{m} \\
(\text { No.30) }\end{array}$ & 23.68 & 76.32 & $60-79$ \\
\hline $\begin{array}{c}300-\mu \mathrm{m} \\
(\mathrm{No} .50)\end{array}$ & 65.69 & 34.25 & $12-40$ \\
\hline $\begin{array}{c}150-\mu \mathrm{m} \\
(\mathrm{No} .100)\end{array}$ & 90.55 & 9.45 & $0-10$ \\
\hline
\end{tabular}

\subsubsection{Coarse Aggregate}

Well rounded river coarse aggregate (gravel), available at natural quarries on the Dijla River, from Samarra area was used with maximum size of aggregate of $14 \mathrm{~mm}$, Table 5 shows the grading of coarse aggregate and 
confirms to (I.Q.S no.45/1984) [12], and table 6 shows the chemical and physical properties.

Table 4. Physical and Chemical Properties of fine aggregate.

\begin{tabular}{|c|c|c|c|}
\hline Properties & Specification & $\begin{array}{c}\text { Test } \\
\text { Results }\end{array}$ & $\begin{array}{c}\text { Limits of } \\
\text { Specification }\end{array}$ \\
\hline $\begin{array}{l}\text { Specific } \\
\text { gravity }\end{array}$ & $\begin{array}{c}\text { ASTM C128- } \\
01[13]\end{array}$ & 2.63 & \\
\hline $\begin{array}{c}\text { Absorption } \\
(\%)\end{array}$ & $\begin{array}{c}\text { ASTM C128- } \\
01 \text { [13] }\end{array}$ & 2.00 & \\
\hline $\begin{array}{c}\text { Dry loose } \\
\text { unit weight } \\
\left(\mathrm{kg} / \mathrm{m}^{3}\right)\end{array}$ & $\begin{array}{c}\text { ASTM } \\
\text { C29/C29M/97 } \\
{[14]}\end{array}$ & 1600 & \\
\hline $\begin{array}{c}\text { Sulfate } \\
\text { content (as } \\
\text { SO3) } \\
(\%)\end{array}$ & $\begin{array}{l}\text { (I.Q.S.) No. } \\
45 / 1984 \text { [12] }\end{array}$ & 0.36 & $\begin{array}{l}0.5 \text { (max. } \\
\text { value) }\end{array}$ \\
\hline $\begin{array}{l}\text { Material } \\
\text { finer than } \\
0.075 \mathrm{~mm} \\
\quad(\%)\end{array}$ & $\begin{array}{l}\text { (I.Q.S.) No. } \\
\text { 45/1984 [14] }\end{array}$ & 3 & $\begin{array}{l}5 \text { (max. } \\
\text { value) }\end{array}$ \\
\hline
\end{tabular}

Table 5. Grading of coarse aggregate.

\begin{tabular}{|c|c|c|}
\hline Sieve size & $\begin{array}{c}\text { Cumulativ } \\
\text { e Passing } \\
\%\end{array}$ & $\begin{array}{c}\text { Limit of IQS } \\
\text { No. [45/1984] [10] }\end{array}$ \\
\hline $12.5-\mathrm{mm}$ & 93.975 & $90-100$ \\
\hline $9.5-\mathrm{mm}$ & 85.462 & $85-100$ \\
\hline $4.75-\mathrm{mm}$ & 16.699 & $10-30$ \\
\hline $2.36 \mathrm{~mm}$ & 0.164 & $0-10$ \\
\hline
\end{tabular}

Table 6. Physical and Chemical Properties of coarse aggregate.

\begin{tabular}{|c|c|c|c|}
\hline Properties & Specification & $\begin{array}{c}\text { Test } \\
\text { Results }\end{array}$ & $\begin{array}{c}\text { Limits of } \\
\text { Specification }\end{array}$ \\
\hline $\begin{array}{c}\text { Specific } \\
\text { Gravity }\end{array}$ & $\begin{array}{c}\text { ASTM C127- } \\
01[15]\end{array}$ & 2.62 & - \\
\hline $\begin{array}{c}\text { Absorption } \\
(\%)\end{array}$ & $\begin{array}{c}\text { ASTM C127- } \\
01[15]\end{array}$ & 0.7 & - \\
\hline $\begin{array}{c}\text { Dry Loose } \\
\text { Unit } \\
\begin{array}{c}\text { Weight } \\
\text { kg/m }\end{array}\end{array}$ & $\begin{array}{c}\text { ASTM } \\
\text { C29/C29M/97 } \\
{[14]}\end{array}$ & 1596 & - \\
\hline $\begin{array}{c}\text { Sulfate } \\
\text { Content } \\
(\text { as SO } \\
(\%)\end{array}$ & $\begin{array}{c}\text { (I.Q.S.) No. } \\
(\%)\end{array}$ & 0.08 & 0.1 \\
(max.value)
\end{tabular}

\section{Mix Water}

Ordinary drinking water was used for the mixing, curing and all concrete works.

\section{Admixtures}

\subsection{Superplasticizer}

A plasticizer of type Sika Visco Crete super E4 has been used as a high range water reducer additive that lends positive effects to fresh concrete such as increased slump without need for additional water, reducing the ratio of water to cement $(\mathrm{w} / \mathrm{c})$, in addition to improve and facilitating the workability and pumping process of concrete, Table 7 shows the chemical and physical properties of the plasticizer.

Table 7. Technical properties of plasticizer.

\begin{tabular}{|c|c|}
\hline $\begin{array}{c}\text { Properties of Plasticizer } \\
\text { Sika Visco Crete Super E4 }\end{array}$ & Activity \\
\hline Brown Liquid & Appearance \\
\hline $1.06 \pm 0.02 \mathrm{~kg} / \mathrm{ltr}$ & Density at $20 \mathrm{C}^{\circ}$ \\
\hline$-6^{\circ} \mathrm{C}$ & Freezing \\
\hline $6-8$ & $\mathrm{pH}$ \\
\hline None & Chloride \\
\hline
\end{tabular}

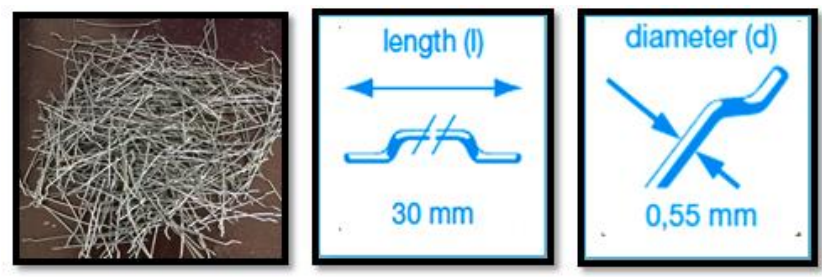

Fig. 1. Dimensions and shape of steel fibers Sika Fiber SH $60 / 30$.

\subsection{Silica fume}

SIKA-FUME-HR was used, it confirms to ASTM C1240-03 [16], and Table 8 shows the properties of SIKA-FUME-HR

Table 8. Chemical analysis and activity index of SIKAFUME-HR

\begin{tabular}{|c|c|c|c|c|}
\hline \multirow{2}{*}{$\begin{array}{c}\text { Pozzolanic } \\
\text { activity }\end{array}$} & \multirow{2}{*}{$\begin{array}{c}\text { Limit } \\
\text { of } \\
\text { ASTM } \\
\text { C1240- } \\
03\end{array}$} & \multicolumn{2}{|c|}{$\begin{array}{c}\text { Chemical } \\
\text { decomposition }\end{array}$} & \multirow{2}{*}{$\begin{array}{c}\text { Limit of } \\
\text { ASTM } \\
\text { C1240- } \\
03 \text { [16] }\end{array}$} \\
\hline & & Oxides & Result\% & \\
\hline \multirow{5}{*}{$121.5 \%$} & \multirow{5}{*}{$105 \%$} & L.O.I & 3.89 & $6 \% \mathrm{Max}$ \\
\hline & & $\mathrm{SiO}_{2}$ & 91.03 & $\begin{array}{l}85 \% \\
\text { Min }\end{array}$ \\
\hline & & $\mathrm{Al}_{2} \mathrm{O}_{3}$ & 4.02 & - \\
\hline & & $\mathrm{Fe}_{2} \mathrm{O}_{3}$ & 0.32 & - \\
\hline & & $\mathrm{SO}_{3}$ & 0.73 & - \\
\hline
\end{tabular}

\section{Steel Fibers}

Steel fibers of type Sika Fiber SH 60/30 were used as shown in Fig. (1), which is the most commonly used species and works to bridge cracks and increases ductility and toughness of concrete. Fibers were of 30 $\mathrm{mm}$ length and diameter of $0.55 \mathrm{~mm}$, fibers were added with replacement ratios of the main reinforcement steel in fraction volumes of $(0.125,0.125$, and 0.375$) \%$ of concrete volume, Table 9 shows the specifications and characteristics of typical steel fibers used in concrete mixtures.

\subsection{Recycled Steel Fiber}

Recycled steel fibers were used from vehicles tires in the local market in Iraq. The fibers were cut manually at uniform length of $30 \mathrm{~mm}$ and $1 \mathrm{~mm}$ diameter and aspect ratio of 30, Fig. (2) Shows the recycled steel fibers used 
Table 9. Pproperties of steel fibers.

\begin{tabular}{|c|c|c|c|}
\hline $\begin{array}{l}\text { Commerc } \\
\text {-ial name }\end{array}$ & Configuration & Property & $\begin{array}{l}\text { Specificati } \\
\text { ons }\end{array}$ \\
\hline \multirow{8}{*}{$\begin{array}{l}\text { Sika } \\
\text { Fiber SH } \\
60 / 30\end{array}$} & \multirow{8}{*}{$\begin{array}{l}\text { Hooked } \\
\text { ends }\end{array}$} & Density & $7860 \mathrm{~kg} / \mathrm{m}^{3}$ \\
\hline & & $\begin{array}{l}\text { Ultimate } \\
\text { strength }\end{array}$ & $1345 \mathrm{MPa}$ \\
\hline & & $\begin{array}{l}\text { Modulus of } \\
\text { Elasticity }\end{array}$ & $\begin{array}{c}210 \times 10^{3} \mathrm{M} \\
\mathrm{Pa}\end{array}$ \\
\hline & & $\begin{array}{l}\text { Strain at } \\
\text { proportion } \\
\text { limit }\end{array}$ & $6.4 \times 10^{-3}$ \\
\hline & & $\begin{array}{l}\text { Poisson's } \\
\text { ratio }\end{array}$ & 0.28 \\
\hline & & $\begin{array}{l}\text { Average } \\
\text { length (Lf) }\end{array}$ & $30 \mathrm{~mm}$ \\
\hline & & $\begin{array}{c}\text { Nominal } \\
\text { diameter(Df) }\end{array}$ & $\begin{array}{l}0.55 \\
\mathrm{~mm}\end{array}$ \\
\hline & & $\begin{array}{c}\text { Aspect ratio } \\
\left(\mathrm{L}_{\mathrm{f}} / \mathrm{D}_{\mathrm{f}}\right)\end{array}$ & 60 \\
\hline
\end{tabular}
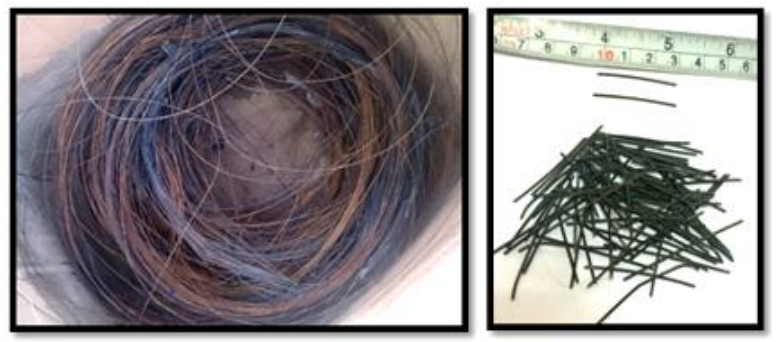

Fig. 2. Recycled steel fiber.

\subsection{Steel Reinforcement}

Deformed steel reinforcement of $6 \mathrm{~mm}$ diameter, were used at the bottom of the slabs to resist tension stresses resulting from bending moment. Table 10 shows the Lab. results conducted on this steel bars and confirms to ASTM A615 [17].

\subsection{Mold Dimensions and Slab Reinforcement Details}

Four steel molds were manufactured with $300 \times 700 \times 70$ $\mathrm{mm}$ in dimensions and thick steel sheets were used to ensure fare faces. The slab samples were designed with rectangular section to ensure bending failure before shear failure is reached, Rebars of $6 \mathrm{~mm} \emptyset$ were used in both directions as shown in Fig. 3.
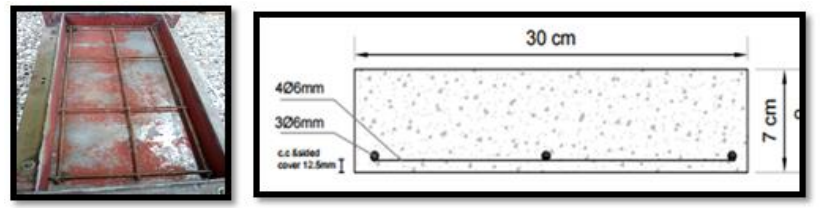

Fig. 3. Details of transverse section of one-way slab.

\subsection{Reference Mix}

The concrete mixture used was designed according to the American Concrete Institute code (ACI 211.4R- 08) ${ }^{[18]}$ to obtain a concrete compressive strength of $35 \mathrm{MPa}$ at the age of twenty-eight days, Superplasticizer was used by $1 \%$, and the silica fume by $10 \%$ by weight of cement. Tables 11,12 shows the weight of the material used in preparing the concrete mixture.

Table 11. Ingredients of reference concrete mixture.

\begin{tabular}{|c|c|c|c|c|c|c|}
\hline Ingredient & $\begin{array}{c}\text { Coarse } \\
\text { aggregate }\end{array}$ & $\begin{array}{c}\text { Fine } \\
\text { aggregate }\end{array}$ & Cement & Water & Superplasticizer & $\begin{array}{c}\text { Silica } \\
\text { Fume }\end{array}$ \\
\hline $\mathrm{Kg} / \mathrm{m}^{3}$ & 898 & 890 & 447 & 137 & 5 & 50 \\
\hline
\end{tabular}

Table 10. Results of steel bars test.

\begin{tabular}{|c|c|c|c|}
\hline $\begin{array}{c}\text { Bars } \\
\text { diameters } \\
(\mathrm{mm})\end{array}$ & $\begin{array}{c}\text { Yield stress } \\
\left(f_{y}\right)(\mathrm{MPa})\end{array}$ & $\begin{array}{c}\text { Ultimate } \\
\text { stress }\left(f_{u}\right) \\
(\mathrm{MPa})\end{array}$ & $\begin{array}{c}\text { Elongation } \\
\%\end{array}$ \\
\hline $6 \mathrm{~mm}$ & 621.81 & 720.34 & 6.4 \\
\hline
\end{tabular}

\section{Mixes, casting, and concrete curing}

Steel molds (slabs, cubes, cylinders, and prisms) are prepared, cleaned and oiled with a thin film of oil, then reinforcement is placed in the steel mold, and the mixing process begins with half quantity of coarse aggregate and water, then fibers (steel fibers or recycled steel fiber) were added gradually to avoid congestion. Finally all other mixing ingredients are added to complete the mix. Slump test is conducted on the mix afterward within 75-125 mm limits. Molds are filled with fresh mix and vibrated at layers of 50mm thickness each [19]. Samples are left for 24 hours, then placed in water for 27 days to have ready for testing of strength. Eight concrete mixes were prepared with two slabs samples from each mix. The eight mixes consist of one mix as a reference mix with no additives and reinforcement. Another mix reinforced but no additives in addition to six mixes with different volumetric ratios of reinforcement as shown in Table XII .

\section{Laboratory tests}

\subsection{Mechanical tests}

\section{compressive strength}

Compressive strength test was conducted according to British specification (BS 1881: Part 116:1989) for standard cubes samples used of $(150 \times 150 \times 150) \mathrm{mm}$. An electrical testing machine of capacity $2025 \mathrm{kN}$ was loaded axially. The average compressive strength value for three cubes was adopted at the age of 28 days, as shown in Table 13.

Table 12. Details of mixtures used.

\begin{tabular}{|c|c|c|c|}
\hline Symbol & Fibers \% From steel & W/C & SP \% \\
\hline R1 & 0 & 0.392 & 0.6 \\
\hline R2 & 0 & 0.392 & 0.6 \\
\hline SF1 & 0.125 & 0.392 & 0.8 \\
\hline SF2 & 0.250 & 0.392 & 0.9 \\
\hline SF3 & 0.375 & 0.392 & 1.0 \\
\hline RSF1 & 0.125 & 0.392 & 0.8 \\
\hline RSF2 & 0.250 & 0.392 & 0.9 \\
\hline RSF3 & 0.375 & 0.392 & 1.0 \\
\hline
\end{tabular}




\section{Splitting Tensile Strength}

A splitting tensile strength test was conducted on the samples according to (ASTM C 496-96) [20]. A U-Test machine was used to test samples of $(150 \times 300) \mathrm{mm}$ cylinders at 28 days age. Three samples were used for each mix, for each percentage ratio of steel and recycled steel proportion of the percentages used for steel and recycled steel fiber. In the test, a diagonal compressive load was applied which will cause tensile failure instead of compressive since the location of applied load will be in the triaxial compression and enable sample to resist compression higher than when under compressive testing. Table 14 shows detailed results of increase or decrease in tensile strength. Fig. (5) Shows the effect of hooked reinforced fiber on bridging cracks compared to samples with unhooked fiber reinforcement.

\section{- Modulus of rupture}

Modulus of rupture $\left(f_{r}\right)$ test was conducted on concrete samples of $(100 \times 100 \times 500) \mathrm{mm}$ with prisms specimens according to ASTM C78-01[21]. Third -point loading method was used at loading rate $(1 \mathrm{MPa} / \mathrm{min})$. Three prisms were used for each type of mix at 28 age. Fig. (6) Shows the mode of failure of samples. While table 15 shows detailed results of using different ratios of fibers. Some results show that reinforcement fibers didn't work well at certain level because level was exposed to tension and compression stresses at the same time. The different mixtures that contained the two types of fiber were adopted for the number of standard prisms and testing. It noted the increase in the ratio of modulus of rupture to increase the ratio of the hooked fibers compared to the reference sample and the increase rates of $(35.41 \%$, $58.20 \%)$ for fibers proportion of $(0.125 \%(0.2 \%)$, while the decrease in fiber fraction $(0.375 \%)$ to be $(26.41 \%)$. This difference may be due to the steel fiber ratio exceeding the normal fraction of the $\mathrm{V}_{\mathrm{f}}$. when comparing the same ratios of both types of fiber a difference was noticed in the amount of increase or decrease of resistance, which requires the study of replacement ratios at additional rates to reach the exact limits of the change in rupture resistance.
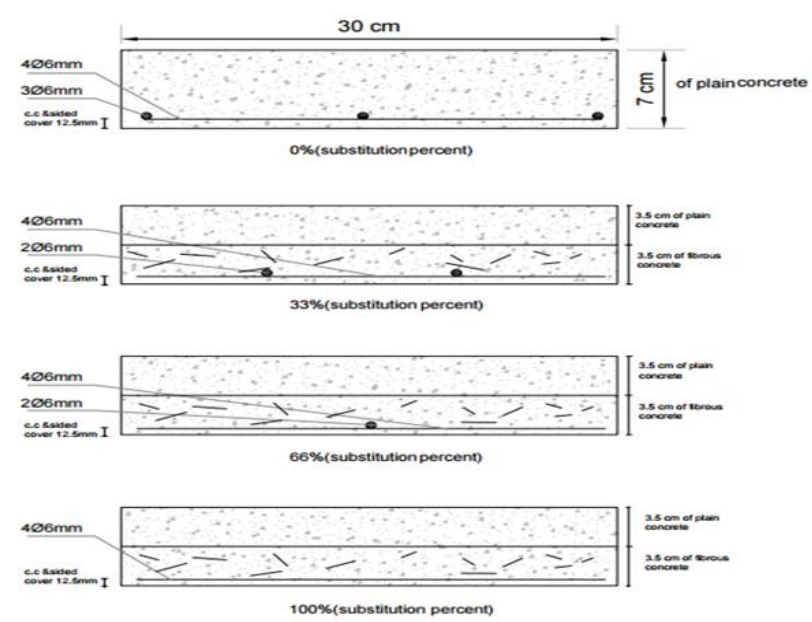

Fig. 4. Details of steel ratios.
Table 13. Compressive strength of reference concrete mixtures.

\begin{tabular}{|c|c|c|c|c|c|c|c|c|}
\hline \multirow{2}{*}{$\begin{array}{l}\text { Group } \\
\text { No. }\end{array}$} & \multirow{2}{*}{$\begin{array}{l}\text { Mix } \\
\text { No. }\end{array}$} & \multicolumn{2}{|c|}{$\begin{array}{c}\text { Steel Fibers } \\
\text { Percentage } \%\left(V_{f}\right)\end{array}$} & \multirow[b]{2}{*}{$\mathrm{W} / \mathrm{C}$} & \multirow{2}{*}{$\begin{array}{l}\text { SP } \\
\%\end{array}$} & \multirow{2}{*}{$\begin{array}{c}\text { Silica } \\
\text { Fume } \\
\text { from } \\
\text { Cement } \\
\%\end{array}$} & \multirow{2}{*}{\begin{tabular}{|c} 
Comp. - \\
Strength \\
$(28)$ day \\
$\left(f_{c u}\right)$ \\
MPa
\end{tabular}} & \multirow{2}{*}{$\begin{array}{c}\text { Av. } \\
\text { Comp. - } \\
\text { Strength } \\
(28) \text { day } \\
\left(f_{c u}\right) \\
\mathrm{MPa}\end{array}$} \\
\hline & & $\begin{array}{c}\mathrm{SF} \\
\text { (Normal) } \\
\%\end{array}$ & $\begin{array}{c}\mathrm{SF} \\
\text { (Recycling) } \\
\%\end{array}$ & & & & & \\
\hline \multirow{3}{*}{ Ref } & 1 & 0 & 0 & 0.392 & 0.6 & 10 & 48.7 & \multirow{3}{*}{44.89} \\
\hline & 2 & 0 & 0 & 0.392 & 0.6 & 11 & & \\
\hline & 3 & 0 & 0 & 0.392 & 0.6 & 10 & 43.73 & \\
\hline
\end{tabular}

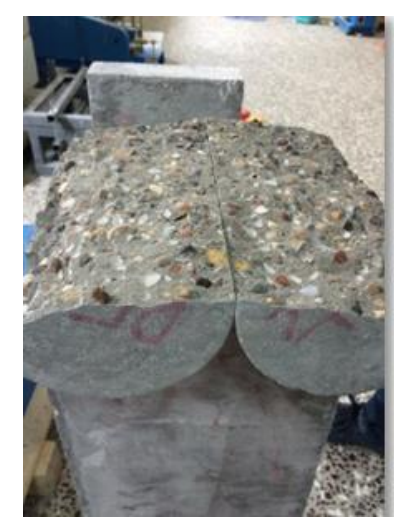

a-without fiber

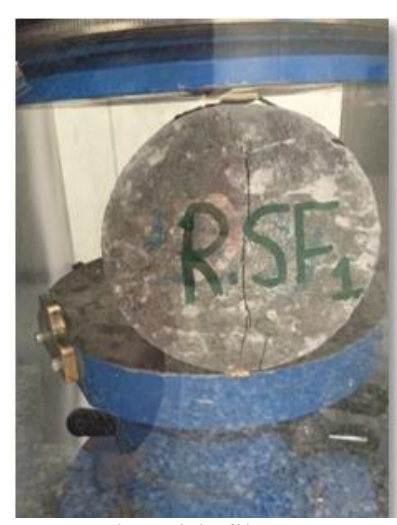

b- with fiber
Fig. 5. Mode of failure of concrete cylindrical samples.
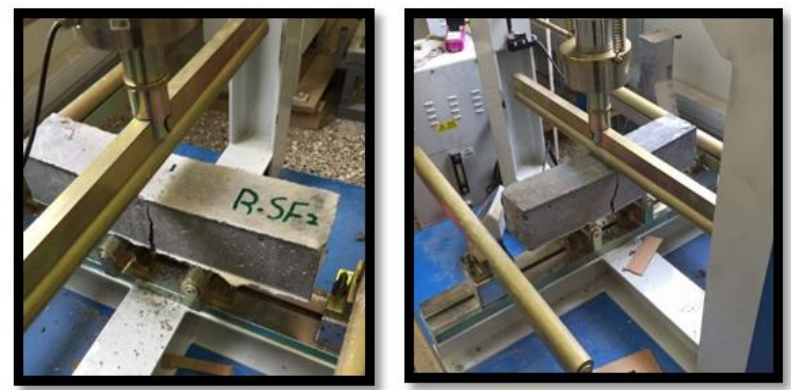

Fig. 6. Mode of failure of prisms.

- Flexural strength test of one way slabs

Slabs of $(700 \times 300 \times 70) \mathrm{mm}$ were tested for flexure at 28 days age. The slabs reinforced identically were simply supported and tested by a flexural testing machine of $200 \mathrm{kN}$ capacity at loading rate $(1 \mathrm{kN} / \mathrm{sec})$. A uniform load was applied with reading taken from a digital gage machine of one micron $(1 \mu \mathrm{mm})$ accuracy. Results were based on load-deflection curves at mid-span. Fig. ( $8 \& 9$ ). Table 16 shows many different cases of the effects of changing reinforcement with typical steel fibers and recycled steel fibers.
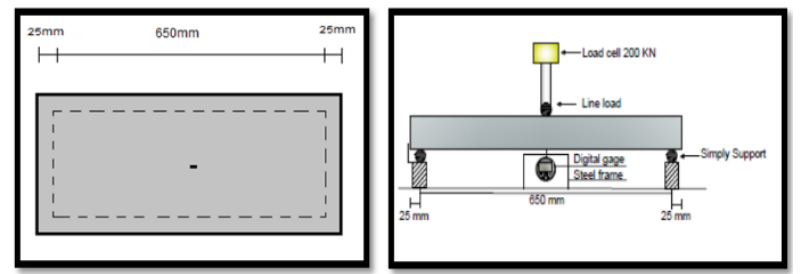

Fig. 7. Details and supporting method.

The replacement of the main reinforcing steel with the steel fibers and the recycled fiber has an effect on the 
maximum load of the concrete slabs. Table 16 shows the results obtained from the bending test, for different ratios of steel fibers $(0.125 \%, 0.250 \%$, and $0.375 \%)$. The maximum load decreases by $20.09 \%, 51.91 \%$ and $48.26 \%$ respectively, compared to the maximum load of the reference slabs. As well as for slump values $(35.18 \%$, $37.03 \%$, and $81.48 \%$ ) compared to the slump values of the reference slabs. This is due to the type of fiber used, as well as the nature of its behavior and the place of addition where it was added to the tensile area only. The maximum load is gradually reduced by $25.72 \%, 36.41 \%$, and the maximum weight is reduced by $25.72 \% 38.29 \%$ ), respectively, compared to the maximum load of slabs $(38.88 \%, 70.37 \%, 79.63 \%)$ compared with the slump values of the reference slabs.

Fig. (10) Shows how slabs with main reinforcement replaced with fibers at $(0.125 \%)$ will have maximum load higher than those slabs with recycled reinforcement of fiber. The same result goes to slump tests and cracks. This is due to the hooks of the reinforcement of normal steel fiber at their ends which spread widely to tension zone and thus give more resistance. Fig. $(11 \& 12)$ show the comparison of slabs with recycled steel fibers and normal steel fibers at $(0.25 \%)$ and $(0.375 \%)$ respectively. The latter gives less strength for the same steel fiber and recycled steel fiber slabs as shown in Fig. 10.

\section{Ductility}

The Ductility Index $(\mu \mathrm{d})$ is defined as the ratio between the deflection at the maximum load of failure to the deflection at the yield of the steel reinforcement [22] which can be determined from the curve (load - deflection) of the slab when the curve moves from the elasticity stage to the plasticity phase, Table 17 shows the values of ductility that were determined from the rate of two slabs for each replacement ratio between the main reinforcement and the ordinary and recycled steel fibers. Based on these results, the highest value of ductility index was 3.77 for the replacement ratio of $0.250 \%$ of main steel reinforcement by steel fibers that increases by $(18.92 \%)$ from the ductility Index for the reference slabs. This is due to the decrease in the deflection for the first cracking or when the reinforcing steel is replaced by the steel fibers instead of the main reinforcing steel which is widely distributed during the mixture, causing a decrease in the value of the deflection. Also, it has been noted that the ductility index has decreased to a large value for a replacement ratios of $(0.125 \%, 0.375 \%)$ compared to the reference tile. When replacing the main steel reinforcement with recycled steel fibers, there is an increase in the value of ductility for a replacement ratio of $(0.125 \%)$ compared to the reference slab, the increase was (4.1\%). Gradual decrease in ductility index has been noted compared to reference slabs for replacement ratios $(0.375 \%, 0.25 \%)$ by $(16.08 \%$ and $30.60 \%)$ respectively. This is due to the increase in the amount of fibers inside the concrete mixture with a decrease in the amount of reinforcing steel which reduces the strength of the stresses generated in the tensile areas at the beginning of the loading. It results a decrease in the rate of deflection at yield and deflection at maximum load of failure, which greatly affects the value of ductility Index.

\section{Stiffness}

The stiffness of the concrete slabs was calculated based on the maximum load of failure for the slabs by taking $45 \%$ of the maximum load and projecting it on the loaddeflection curve and determines the value of the deflection corresponding to the load and dividing the calculated load on the resulting deflection ${ }^{[23]}$. Table 18 shows the stiffness values of concrete slabs. The results show that the highest stiffness value of slabs at a replacement ratio of $(0.125 \%)$ of the main reinforcement by steel fibers in the second group (G2) which has increased by $(61.85 \%)$ than the stiffness value of the reference slabs (R2), and the highest stiffness in the first group $(\mathrm{G} 1)$ at a replacement ratio of $(0.125 \%)$ of the main reinforcing steel by the steel fibers, which is $(18.58 \%)$ higher than the stiffness of the reference slabs (R2). The stiffness values of the second group (G2) slabs with reinforcing steel replacement ratios by recycled steel fibers are higher than the stiffness values of the first group (G1) slabs, and their stiffness is also higher than the stiffness of the reference slabs. The stiffness of this group gradually decreases with an increase of fibers content, due to reasons such as the type of fiber used, their size and their distribution. The addition of these fibers in the tensile area only, which greatly affects the maximum deflection values and the deflection at the first crack, as well as the maximum load, giving high stiffness values compared to reference slabs and that contain steel fibers.

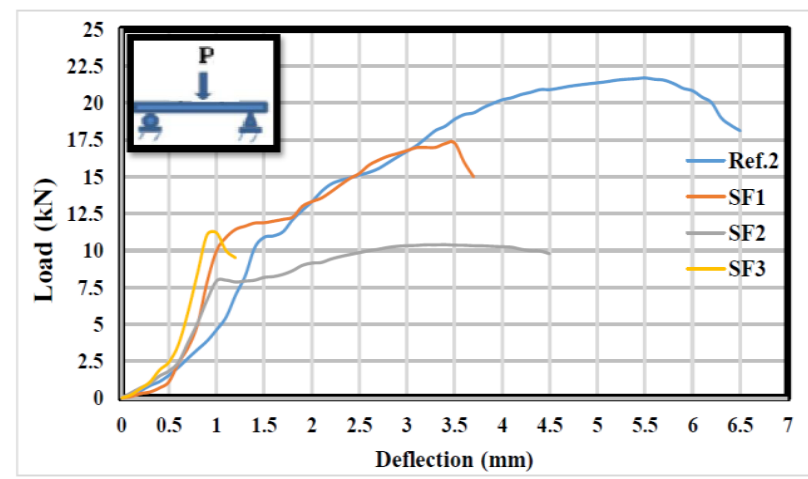

Fig. 8. Load-deflection relationship at mid-span of concrete slabs.

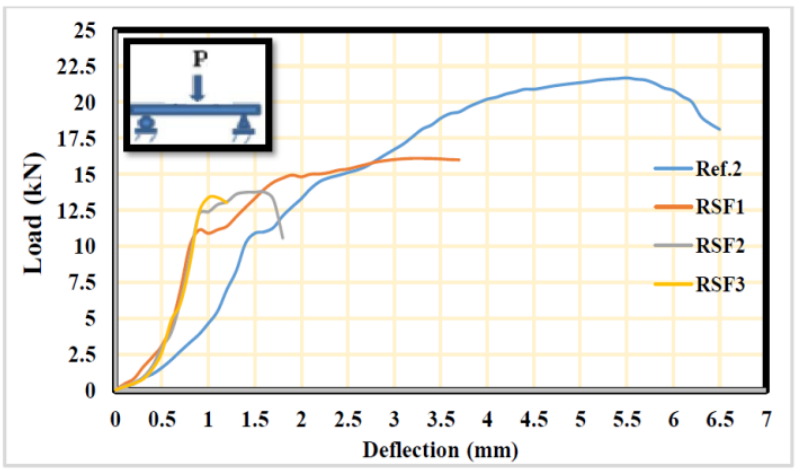

Fig. 9. Load- deflection relationship at mid-span of concrete slabs. 


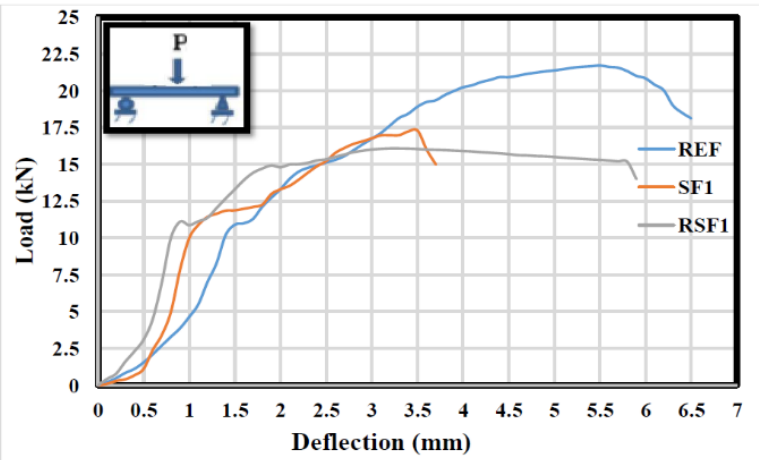

Fig.10. load-deflection relationship at mid-span of concrete slabs

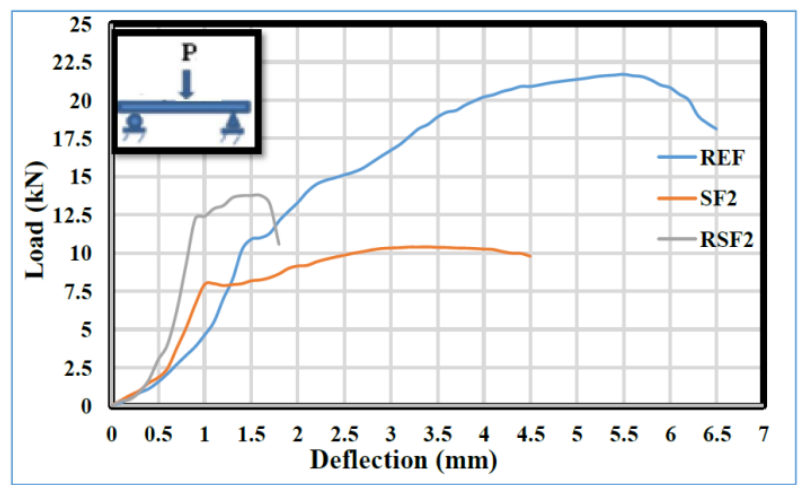

Fig.11. load-deflection relationship at mid-span of concrete slabs

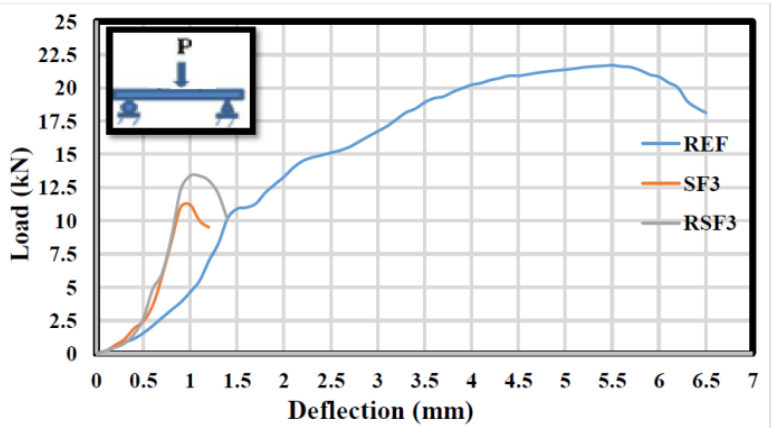

Fig.12. load-deflection relationship at mid-span of concrete slabs

\section{Conclusions}

It has been concluded that;

1. The max. Failure load in flexure and deflection has decreased by $20.09 \%$ to $51.91 \%$ of max. Load and by $35.18 \%$ to $81.48 \%$ in one-way slabs compared with refrenece slab, upon replacing main steel reinforcement by steel fibers.

2. The max. Failure load in flexure and deflection has decreased by $25.72 \%$ to $38.29 \%$ of max. Load and by $38.88 \%$ to $79.63 \%$ in one-way slabs compared with refrenece slab, upon replacing main steel reinforcement by recycled steel fibers.

3. The best values of max. Load and deflection were at replacement ratio of $0.125 \%$ of main steel reinforcement by recycled ones.

4. The heighest value of ductility obtained was 3.77 at replacement ratio $0.25 \%$ of main steel reinforcement by steel fibers.

5. The highest value of hardness obtained was 11.76 $\mathrm{kN} / \mathrm{mm}$ at replacement ratio $0.125 \%$ of main steel reinforcement by recycled steel fibers, and increased by $61.85 \%$ than that of reference slabs.

\section{References}

[1] Brown R., Shukla A., Natarajan K.R., "Fiber Reinforcement of Concrete Structure", University of Rhode, Island, Transportation Center, Sep. 2002

[2] Dhonde, Hemant B. ,Mo, Y.L. ,Thomas,T.C. ,"Fiber Reinforcement in Prestressed Concrete Beams", University of Hoston, Department of Civil Engineering \& Environmental Engineering, 2005.

[3] ACI Committee 544, "State-of-the Art Report on Fibre Reinforced Concrete", Sp-81 ACI Publication, International Symposium on Fiber Reinforced Concrete, pp. 411-431, 1984.

[4] Hannant, D."Fiber Cement and Fiber Concrete", Wiley, Chichester, 1987.

[5] Shah, R. H., \& Mishra, S. V. "Crack and Deformation Characteristics of SFRC Deep Beams" Journal of the Institution of Engineers. India. Civil Engineering Division, 85(mai), pp. 44-48, 2004.

[6] Hannant, D.J., "Fibre Cement and Fibre Concrete", Properties in the Hardend State, Chapter 6, John Wiley and Sons, Chichester, 1978, pp. 61-80.

[7] COSQC, Standard Specification for Portland Cement, Iraqi Specif. 5 (1984).

[8] ASTM C114-01 "Standard Test Methods for Chemical Analysis of Hydraulic Cement ", ASTM Standard, vol. 04.02, pp. 1 - 4, 2004.

[9] ASTM C204-00 "Standard Test Method for Fineness of Hydraulic Cement by Air-Permeability Apparatus", ASTM Standards, vol. 04.02, pp. 1 - 9, 2004.

[10] ASTM C191-04 "Standard Test Method for Time of Setting of Hydraulic Cement by Vicat Needle", ASTM Standards, Vol. 04.02, 2004.

[11] ASTM C 109 / C 109M - 07 "Standard Test Method for Compressive Strength of Hydraulic Cement Mortars (Using 2-in. or [50-mm] Cube Specimens)".

[12] Iraqi Standard no. 45, "Natural Aggregate used in Construction Works", Central Directorate of Standardization and Quality Control.

[13] ASTM C128 - 01 "Standard Test Method for Density، Relative Density (Specific Gravity)، and Absorption of Fine Aggregate", ASTM Standards, Vol. 04.02, 2004.

[14] ASTM C29 / C29M - 97 (Re - approved 2003), "Standard Test Method for Bulk Density 15(Unit Weight) and Voids in Aggregate", ASTM Standards, Vol. 04.02, pp. 1-4, 2004.

[15] ASTM C127-01, "Standard Test Method for Density, Relative Density (Specific Gravity), and Absorption of Coarse Aggregate1", ASTM Standards, Vol. 04.02, pp. $1-6,2004$ 
[16] ASTM C1240 - 03, "Standard Specification for Use of Silica Fume as a Mineral Admixture in HydraulicCement Concrete, Mortar, and Grout" ASTM Standards, 2004

[17] ASTM A615 / A615M - 09, "Standard Specification for Deformed and Plain Carbon-Steel Bars for Concrete Reinforcement".

[18] ACI Committee 211" Guide for Selecting Proportions for High-Strength Concrete Using Portland Cement and Other Cementitious Materials ", ACI 211.4R-08, 2008.

[19] Alyaa AlAtaar, "Micro structure and Mechanical Properties of Lightweight Aggregate Concrete Containing Fibers".

[20] ASTM C 496 - 96 "Standard Test Method for Splitting Tensile Strength of Cylindrical Concrete Specimens

[21] ASTM C78-02, "Stander test method for flexural strength of concrete (using samples beam with third point loading" ASTM standards, vol. 04.02, 2004.

[22] Elavenil S. , Samuel K., G. M ,"Behavior of Steel Fiber Reinforced Concrete Beams and Plates Under Static Load" , Journal of Research in Science , Computing and Engineering, vol. 4, no. 3, pp. 11-28, 2007.

[23] Al-Jwari, Ruaa S., “ Behavior of reinforced concrete beams strengthening by Polymer carbon fibers fixed near top surface, M.Sc Thesis, University of Mosul, 2010 .

Table 14. Results of splitting tensile strength

\begin{tabular}{|c|c|c|c|c|c|c|c|c|}
\hline \multirow[b]{2}{*}{$\begin{array}{l}\text { Group } \\
\text { No. }\end{array}$} & \multirow[b]{2}{*}{$\begin{array}{l}\text { Mix } \\
\text { No. }\end{array}$} & \multirow[b]{2}{*}{$\mathrm{W} / \mathrm{C}$} & \multicolumn{2}{|c|}{ Steel Fibers Percentage $\left(V_{f}\right)$} & \multirow[b]{2}{*}{$\mathrm{SP} \%$} & \multirow[b]{2}{*}{$\begin{array}{l}\text { Silica } \\
\text { Fume } \\
\%\end{array}$} & \multirow[b]{2}{*}{$\begin{array}{l}\text { Splitting Tensile } \\
\text { Strength }(28) \text { day } \\
\left(f_{t}\right) \mathrm{MPa}\end{array}$} & \multirow[b]{2}{*}{$\begin{array}{c}\text { Increase or } \\
\text { decrease } \\
\%\end{array}$} \\
\hline & & & $\begin{array}{c}\mathrm{SF} \\
\text { (Normal) } \\
\% \\
\end{array}$ & $\begin{array}{c}\mathrm{SF} \\
\text { (Recycling) \% }\end{array}$ & & & & \\
\hline Ref & $\mathrm{R}$ & 0.392 & 0 & 0 & 0.6 & 10 & 3.91 & - \\
\hline \multirow{3}{*}{ G1 } & SF1 & 0.392 & 0.125 & 0 & 0.8 & 10 & 4.29 & +9.71 \\
\hline & SF2 & 0.392 & 0.250 & 0 & 0.9 & 10 & 5.35 & +38.83 \\
\hline & SF3 & 0.392 & 0.375 & 0 & 1.0 & 10 & 3.57 & -8.70 \\
\hline \multirow{3}{*}{ G2 } & RSF1 & 0.392 & 0 & 0.125 & 0.8 & 10 & 3.13 & 19.95- \\
\hline & RSF2 & 0.392 & 0 & 0.250 & 0.9 & 10 & 3.40 & -13.04 \\
\hline & RSF3 & 0.392 & 0 & 0.375 & 1.0 & 10 & 3.32 & -15.09 \\
\hline
\end{tabular}

Table 15. Modulus of rupture for different concrete mixes with steel fiber ratios.

\begin{tabular}{|c|c|c|c|c|c|c|c|c|}
\hline \multirow[b]{2}{*}{ Group No. } & \multirow[b]{2}{*}{ Mix No. } & \multirow[b]{2}{*}{$\mathrm{W} / \mathrm{C}$} & \multicolumn{2}{|c|}{ Steel Fibers Percentage $\%\left(V_{f}\right)$} & \multirow[b]{2}{*}{$\mathrm{SP} \%$} & \multirow[b]{2}{*}{$\begin{array}{c}\text { Silica } \\
\text { Fume \% }\end{array}$} & \multirow[b]{2}{*}{$\begin{array}{l}\text { Modulus of } \\
\text { Rapture }(28) \\
\text { day }\left(f_{r}\right) \mathrm{MPa}\end{array}$} & \multirow[b]{2}{*}{$\begin{array}{c}\text { Increase or } \\
\text { decrease } \\
\%\end{array}$} \\
\hline & & & SF (Normal) $\%$ & $\begin{array}{c}\text { SF (Recycling) } \\
\%\end{array}$ & & & & \\
\hline Ref & $\mathrm{R}$ & 0.392 & 0 & 0 & 0.6 & 10 & 6.89 & - \\
\hline \multirow{3}{*}{ G1 } & SF1 & 0.392 & 0.125 & 0 & 0.8 & 10 & 9.33 & +35.41 \\
\hline & SF2 & 0.392 & 0.250 & 0 & 0.9 & 10 & 10.9 & +58.20 \\
\hline & SF3 & 0.392 & 0.375 & 0 & 1 & 10 & 8.71 & +26.41 \\
\hline \multirow{3}{*}{ G2 } & RSF1 & 0.392 & 0 & 0.125 & 0.8 & 10 & 10.16 & +47.46 \\
\hline & RSF2 & 0.392 & 0 & 0.250 & 0.9 & 10 & 9.46 & +37.30 \\
\hline & RSF3 & 0.392 & 0 & 0.375 & 1 & 10 & 9.96 & +44.55 \\
\hline
\end{tabular}


Table 16. Results of maximum load and first crack load of one - way concrete slabs.

\begin{tabular}{|c|c|c|c|c|c|c|c|c|c|c|c|c|}
\hline \multirow{2}{*}{$\begin{array}{l}\text { Gr. } \\
\text { No. }\end{array}$} & \multirow{2}{*}{$\begin{array}{l}\text { Slabs } \\
\text { No. }\end{array}$} & \multirow[b]{2}{*}{$\mathrm{W} / \mathrm{C}$} & \multicolumn{2}{|c|}{$\begin{array}{l}\text { Steel Fibers Percentage \% } \\
\left(V_{f}\right)\end{array}$} & \multirow[b]{2}{*}{$\mathrm{SP} \%$} & \multirow{2}{*}{$\begin{array}{l}\text { Silica } \\
\text { Fume } \\
\%\end{array}$} & \multirow{2}{*}{$\begin{array}{c}\text { Load at } \\
\text { First } \\
\text { Crack } \\
\mathrm{P}_{\mathrm{cr}} \\
(\mathrm{kN})\end{array}$} & \multirow{2}{*}{$\begin{array}{l}\left(\delta_{c r}\right) \\
(\mathrm{mm})\end{array}$} & \multirow{2}{*}{$\begin{array}{l}\text { Average } \\
\text { Failure } \\
\text { Load }\left(\mathrm{P}_{\mathrm{u}}\right) \\
(\mathrm{kN})\end{array}$} & \multirow{2}{*}{$\begin{array}{l}\text { decrease } \\
\text { in }\left(\mathrm{P}_{\mathrm{u}}\right)\end{array}$} & \multirow{2}{*}{$\begin{array}{c}\left(\delta_{u}\right) \\
(\mathrm{mm})\end{array}$} & \multirow{2}{*}{$\begin{array}{c}\text { decrease } \\
\text { in } \\
\left(\delta_{u}\right) \%\end{array}$} \\
\hline & & & $\begin{array}{c}\text { SF } \\
\text { (Normal) } \\
\% \\
\end{array}$ & $\begin{array}{c}\text { SF } \\
\text { (Recycling) \% }\end{array}$ & & & & & & & & \\
\hline \multirow{2}{*}{ Ref } & R1 & 0.392 & 0 & 0 & 0.6 & 10 & - & - & 8.14 & - & & - \\
\hline & R2 & 0.392 & 0 & 0 & 0.6 & 10 & 11.30 & 1.7 & 21.65 & - & 5.4 & - \\
\hline \multirow{3}{*}{ G1 } & SF1 & 0.392 & 0.125 & 0 & 0.8 & 10 & 11.87 & 1.4 & 17.3 & $20.09 \%$ & 3.5 & $35.18 \%$ \\
\hline & SF2 & 0.392 & 0.250 & 0 & 0.9 & 10 & 6.66 & 0.9 & 10.41 & $51.91 \%$ & 3.4 & $37.03 \%$ \\
\hline & SF3 & 0.392 & 0.375 & 0 & 1 & 10 & 1.90 & 0.4 & 11.2 & $48.26 \%$ & 1 & $81.48 \%$ \\
\hline \multirow{3}{*}{ G2 } & RSF1 & 0.392 & 0 & 0.125 & 0.8 & 10 & 10.88 & 1 & 16.08 & $25.72 \%$ & 3.3 & $38.88 \%$ \\
\hline & RSF2 & 0.392 & 0 & 0.250 & 0.9 & 10 & 4.01 & 0.6 & 13.77 & $36.41 \%$ & 1.6 & $70.37 \%$ \\
\hline & RSF3 & 0.392 & 0 & 0.375 & 1 & 10 & 2.63 & 0.5 & 13.36 & $38.29 \%$ & 1.1 & $79.63 \%$ \\
\hline
\end{tabular}

Table 17. Ductility Index of Reinforcement concrete slabs.

\begin{tabular}{|c|c|c|c|c|c|c|c|c|c|}
\hline \multirow[b]{2}{*}{$\begin{array}{l}\text { Group } \\
\text { No. }\end{array}$} & \multirow[b]{2}{*}{ Mix No. } & \multirow[b]{2}{*}{$\mathrm{W} / \mathrm{C}$} & \multicolumn{2}{|c|}{ Steel Fibers Percentage $\left(V_{f}\right)$} & \multirow[b]{2}{*}{$\mathrm{SP} \%$} & \multirow[b]{2}{*}{$\begin{array}{l}\text { Silica } \\
\text { Fume \% }\end{array}$} & \multirow[b]{2}{*}{$\begin{array}{l}\left(\delta_{y}\right) \\
(\mathrm{mm})\end{array}$} & \multirow[b]{2}{*}{$\begin{array}{l}\left(\delta_{y}\right) \\
(\mathrm{mm})\end{array}$} & \multirow[b]{2}{*}{$\begin{array}{l}\text { Ductility index } \\
\qquad\left(\mu_{d=\delta_{u} / \delta_{y}}\right)\end{array}$} \\
\hline & & & $\begin{array}{c}\text { SF (Normal) } \\
\%\end{array}$ & $\begin{array}{c}\text { SF (Recycling) } \\
\%\end{array}$ & & & & & \\
\hline Ref & R2 & 0.392 & 0 & 0 & 0.6 & 10 & 1.7 & 5.4 & 3.17 \\
\hline \multirow{3}{*}{ G1 } & SF1 & 0.392 & 0.125 & 0 & 0.8 & 10 & 1.4 & 3.5 & 2.5 \\
\hline & SF2 & 0.392 & 0.250 & 0 & 0.9 & 10 & 0.9 & 3.4 & 3.77 \\
\hline & SF3 & 0.392 & 0.375 & 0 & 1.0 & 10 & 0.4 & 1.0 & 2.5 \\
\hline \multirow{3}{*}{$\mathrm{G} 2$} & RSF1 & 0.392 & 0 & 0.125 & 0.8 & 10 & 1.0 & 3.3 & 3.3 \\
\hline & RSF2 & 0.392 & 0 & 0.250 & 0.9 & 10 & 0.6 & 1.6 & 2.66 \\
\hline & RSF3 & 0.392 & 0 & 0.375 & 1.0 & 10 & 0.5 & 1.1 & 2.2 \\
\hline
\end{tabular}

Table 18. Results of stiffness of one - way concrete slabs.

\begin{tabular}{|c|c|c|c|c|c|c|c|c|c|c|c|}
\hline \multirow{2}{*}{$\begin{array}{l}\text { Gr. } \\
\text { No. }\end{array}$} & \multirow{2}{*}{$\begin{array}{l}\text { Slabs } \\
\text { No. }\end{array}$} & \multirow[b]{2}{*}{$\mathrm{W} / \mathrm{C}$} & \multicolumn{2}{|c|}{$\begin{array}{l}\text { Steel Fibers Percentage \% } \\
\qquad\left(V_{f}\right)\end{array}$} & \multirow[b]{2}{*}{$\mathrm{SP} \%$} & \multirow{2}{*}{$\begin{array}{l}\text { Silica } \\
\text { Fume } \\
\%\end{array}$} & \multirow[b]{2}{*}{$\begin{array}{c}\mathrm{P}_{\mathrm{u}} \\
(\mathrm{kN})\end{array}$} & \multirow{2}{*}{$\begin{array}{c}(45 \% \\
\left.\mathrm{P}_{\mathrm{u}}\right) \\
(\mathrm{kN})\end{array}$} & \multirow{2}{*}{$\begin{array}{c}\text { Deflection } \\
@ 45 \%(\mathrm{Pu}) \\
(\mathrm{mm})\end{array}$} & \multirow{2}{*}{$\begin{array}{c}\begin{array}{c}\text { Stiffness } \\
(\mathrm{kN} / \mathrm{mm})\end{array} \\
\text { St }=\frac{45 \% \mathrm{pu}}{\delta \mathrm{u} @ 45 \% \mathrm{pu}}\end{array}$} & \multirow{2}{*}{$\begin{array}{c}\text { Increasing } \\
\%)\end{array}$} \\
\hline & & & $\begin{array}{c}\text { SF } \\
\text { (Normal) } \\
\%\end{array}$ & $\begin{array}{c}\mathrm{SF} \\
\text { (Recycling) \% }\end{array}$ & & & & & & & \\
\hline \multirow{2}{*}{ Ref } & R1 & 0.392 & 0 & 0 & 0.6 & 10 & 8.14 & 3.78 & - & - & - \\
\hline & R2 & 0.392 & 0 & 0 & 0.6 & 10 & 21.65 & 9.74 & 1.35 & 7.21 & - \\
\hline \multirow{3}{*}{ G1 } & SF1 & 0.392 & 0.125 & 0 & 0.8 & 10 & 17.3 & 7.78 & 0.91 & 8.55 & 18.58 \\
\hline & SF2 & 0.392 & 0.250 & 0 & 0.9 & 10 & 10.41 & \begin{tabular}{|l|l|}
4.68 \\
\end{tabular} & 0.75 & 6.24 & -13.45 \\
\hline & SF3 & 0.392 & 0.375 & 0 & 1 & 10 & 11.2 & 5.04 & 0.70 & 7.20 & -0.13 \\
\hline \multirow{3}{*}{ G2 } & RSF1 & 0.392 & 0 & 0.125 & 0.8 & 10 & 16.08 & 7.24 & 0.62 & 11.67 & 61.85 \\
\hline & RSF2 & 0.392 & 0 & 0.250 & 0.9 & 10 & 13.77 & 6.19 & 0.60 & 10.31 & 42.99 \\
\hline & RSF3 & 0.392 & 0 & 0.375 & 1 & 10 & 13.36 & 6.01 & 0.60 & 10.01 & 38.83 \\
\hline
\end{tabular}

